\title{
Anti-Nutrient, Phytochemical and Antiradical Evaluation of 10 Amaranth (Amaranthus spp.) Varieties Before and After Flowering
}

\author{
W. A. Nyonje ${ }^{1}$, A. O. Makokha ${ }^{1} \&$ M. O. Abukutsa-Onyango ${ }^{2}$ \\ ${ }^{1}$ Department of Food Science and Technology, Jomo Kenyatta University of Agriculture and Technology, Nairobi, \\ Kenya \\ ${ }^{2}$ Department of Horticulture, Jomo Kenyatta University of Agriculture and Technology, Nairobi, Kenya \\ Correspondence: W. Akinyi Nyonje, Department of Food Science and Technology, Jomo Kenyatta University of \\ Agriculture and Technology, P.O. Box 62000-00200, Nairobi, Kenya. Tel: 254-723-363-401. E-mail: \\ winnienyonje2012@gmail.com
}

Received: January 14, 2014 Accepted: February 26, 2014 Online Published: March 15, 2014

doi:10.5539/jas.v6n4p68 URL: http://dx.doi.org/10.5539/jas.v6n4p68

\begin{abstract}
Amaranth (Amaranthus spp.) vegetable is widely consumed in Kenya and contributes to the alleviation of food insecurity. It is reported to have bioactive components such as antioxidants that help in protecting the body from long-term degenerative diseases. However, amaranth vegetable has also been shown to contain some anti-nutrients such as tannins, phytic acid, oxalates and nitrates which may bind nutrients and reduce their bioavailability in the body. There are many amaranth varieties and there is very little information about differences in the anti-nutrient and phytochemical levels among the varieties. The objective of this study was to determine the phytochemical and anti-nutrient content of ten amaranth varieties at two growth stages, before and after flowering. The study was in Jomo Kenyatta University of Agriculture and Technology. Ten amaranth varieties, eight of which are new varieties, were planted. Harvesting was done in two stages, at vegetative stage and post flowering stage. The leaves were analyzed for nitrates, vitamin $\mathrm{C}$, total carotenoids, flavonoids and total antioxidant activity. Results showed decrease in nitrates which reduced by about $40 \%$ as the plants matured. The leaves also increased antioxidant activity as the plants matured with the concentration equivalent $\left(\mathrm{IC}_{50}\right)$ with $\mathrm{DPPH}$ of $2 \mathrm{mg} / \mathrm{mL}$ at vegetative stage and about $1 \mathrm{mg} / \mathrm{mL}$ after flowering. In conclusion, as the plants grow older, there was an increased accumulation of anti-nutrient and other plant chemicals. Antioxidant activity is however increased.
\end{abstract}

Keywords: Amaranth, malnutrition, anti-nutrients, phytochemicals, antioxidant activity

\section{Introduction}

Amaranth (Amaranthus spp.) is one of the African leafy vegetables from the family Amaranthaceae, and is believed to have originated from Africa, the Americas and Europe. It is an herbaceous annual crop cultivated for both its leaves which are used as a vegetable and its seeds which are used as a grain. It is also often found growing wildly. Vegetables including amaranth are an important component of the diet as they provide important nutrients and also have bioactive components such as antioxidants that help protect the body from long-term degenerated diseases (Raheena, 2007). However, the amaranth vegetable has also been shown to contain some anti-nutrients such as tannins, phytic acid, oxalates and nitrates. These antinutrients bind nutrients and may reduce their bioavailability in the body (Abara, 2003; Agbaire \& Emoyan, 2012).

Amaranth, just as other African leafy vegetables, has been a staple food to many African and Kenyan households for a long time. Some of its vernacular names in Kenya include Ododo (Luo), Mchicha (Swahili) Terere (kikuyu) Chimboka (luhya), Ekwala (teso), Lookwa or Epespes (turkana); (Jacob, 2005).

Approximately 60 species are recognized, with inflorescences and foliage ranging from purple and red to green or gold. They produce edible leaves while others produce grains as well (Grubben, 2004). They are also used as ornamentals while others are just weeds (He, 2002; Kauffman \& Weber, 1990). Many varieties and cultivars of amaranth, both vegetable and grain are in existence. Further, new varieties, with unknown phytochemical and anti-nutritional characteristics are still being produced.

The objective of this study was to determine the phytochemical, anti-nutrient content and antiradical activity of ten amaranth varieties at two growth stages, before and after flowering. 


\section{Materials and Methods}

\subsection{Research Site}

The study was carried out in Jomo Kenyatta University of Agriculture and Technology (JKUAT) in the year 2013.

\subsection{Experimental Design and Treatments}

The experiment was laid in randomized complete block design (RCBD) and replicated three times. The treatments comprised ten different amaranth varieties, which were harvested at two growth stages, the vegetative stage and post flowering stage.

\subsection{Crop Establishment}

The ten varieties were planted on a $10 \mathrm{~m}$ by $5 \mathrm{~m}$ plot in JKUAT farm, in rows of $50 \mathrm{~cm}$ apart. Blocks were $2 \mathrm{~m}$ long and the distance between blocks was $1 \mathrm{~m}$. Rainfall and irrigation were the sources of water for the crops. In the weeks where there was no rain, the plants were irrigated twice a week. Shallow cultivation using Jembes and hand pulling of weeds was carried out to keep the plot weed free.

\subsection{Experimental Material}

This consisted of ten amaranth varieties, eight advanced lines and two standard varieties.

Table 1. Experimental material

\begin{tabular}{lllll}
\hline Var. No & Variety name & Status & Botanical name & Comments \\
\hline 1 & Abuku amaranth 1 & Advanced line & Amaranthus blitum & Being evaluated byKEPHIS \\
2 & Abuku amaranth 2 & Advanced line & Amaranthus blitum & Being evaluated by KEPHIS \\
3 & Abuku amaranth 3 & Advanced line & Amaranthus hybridus & Being evaluated by KEPHIS \\
4 & Abuku amaranth 4 & Advanced line & Amaranthus hybridus & Being evaluated by KEPHIS \\
5 & Abuku amaranth 5 & Advanced line & Amaranthus hybridus & Being evaluated by KEPHIS \\
6 & Abuku amaranth 6 & Advanced line & Amaranthus hybridus & Being evaluated by KEPHIS \\
7 & Abuku amaranth 7 & Advanced line & Amaranthus dubius & Being evaluated by KEPHIS \\
8 & Abuku amaranth 8 & Advanced line & Amaranthus hypocandracus & Being evaluated by KEPHIS \\
9 & Natures best amaranths & Standard variety & Amaranthus hybridus & Safari seed Co. Ltd \\
10 & Amaranths (terere) & Standard variety & Amaranthus dubius & Simlaw seed Co. \\
\hline
\end{tabular}

\subsection{Harvesting/Sample Collection}

Leaves were harvested at the vegetative stage, four weeks after planting and after flowering at about seven weeks after planting. The leaves were harvested by hand plucking and were then put in polythene bags and stored in a cold room awaiting laboratory analysis.

\subsection{Phytochemical and Anti-Nutrient Analysis}

Analysis was done on the anti-nutrient content (nitrates), vitamin C, carotenoids, flavonoids and antioxidant activity, more specifically antiradical activity.

\subsubsection{Determination of Nitrates}

The nitrate content in the test samples was determined by the calorimetric method using salicylic acid according to Cataldo et al. (1975). A $500 \mathrm{mg}$ fresh leaves was weighed and put in a tube. Ten $\mathrm{mL}$ of hot $\left(90-95^{\circ} \mathrm{C}\right)$ distilled water was added. The closed tubes were placed in a water bath at $80^{\circ} \mathrm{C}$ for 30 minutes and shaken. The samples were cooled and centrifuged at $4500 \mathrm{rpm}$. Supernatant was decanted and weighed to determine the exact volume of extract. Chlorophyll in leaves was removed by adding $0.5 \mathrm{~g} \mathrm{MgCO}_{3}$ to the supernatant, and centrifuged again. The supernatant containing the nitrate extract was treated with $2 \mathrm{~N} \mathrm{NaOH}$ and a combination of salicylic acid and $\mathrm{H}_{2} \mathrm{SO}_{4}$. Nitrate standards were also prepared using sodium nitrate calibration curve. Absorption was measured at $410 \mathrm{~nm}$ with UV-Vis spectrophotometer (Shimadzu model UV - 1601 PC, Kyoto, Japan). 


\subsubsection{Determination of Vitamin C}

The ascorbic acid content in the samples was determined by HPLC method according to Vikram et al. (2005). About $2 \mathrm{~g}$ sample was be weighed and extracted with $0.8 \%$ metaphosphoric acid. This was made to $20 \mathrm{~mL}$ of juice. The juice was centrifuged at $10000 \mathrm{rpm}$ for 10 minutes. The supernatant was filtered and diluted with 10 $\mathrm{mL}$ of $0.8 \%$ metaphosphoric acid. This was passed through $0.45 \mu$ filter and $20 \mu \mathrm{L}$ injected into the HPLC machine. Various concentrations of ascorbic acid standards were also made to make a calibration curve. HPLC analysis was done using Shimdzu UV-VIS detector. The mobile phase was $0.8 \%$ metaphosphoric acid, at 1.2 $\mathrm{mL} / \mathrm{min}$ flow rate and wavelength of $266.0 \mathrm{~nm}$.

\subsubsection{Determination of Total Carotenoids}

Total carotenoids were extracted using acetone and analyzed using column chromatography and UV Spectrophotometer, (Rodriguez-Amaya \& Kimura, 2004; AOAC, 1996). Approximately 2 grams fresh sample was weighed, chopped finely and placed in a motar with about $10 \mathrm{~mL}$ of acetone. This was thoroughly ground and the acetone extract transferred into $100 \mathrm{~mL}$ volumetric flask. The residue was again extracted with $10 \mathrm{~mL}$ acetone and the extract was added to the contents of the volumetric flask. The extraction with acetone was continued until the residue no longer gave colour. The combined extract was made to a volume of $10 \mathrm{~mL}$ with acetone.

Exactly $25 \mathrm{~mL}$ of the extract was evaporated to dryness using rotary evaporator. The residue was dissolved with 10 $\mathrm{mL}$ petroleum ether and the solution introduced into a chromatographic column. This was eluted with petroleum ether and beta carotene collected in a flask. The beta carotene elute was made to a volume of $25 \mathrm{~mL}$ with petroleum ether and the absorbance was read at $450 \mathrm{~nm}$ in a UV-Vis spectrophotometer (Shimadzu model UV - $1601 \mathrm{PC}$, Kyoto, Japan). Total carotenoid was calculated using the formula:

$$
\text { Total carotenoid content }(\mu \mathrm{g} / \mathrm{g})=\mathrm{A} * \text { volume }(\mathrm{mL}) * 104 \div \mathrm{A}^{1 \%}{ }_{1 \mathrm{~cm}} * \text { sample wt }(\mathrm{g})
$$

Where $\mathrm{A}=$ absorbance; volume $=$ total volume of extract $(25 \mathrm{~mL}) ; \mathrm{A}^{1 \%}{ }_{1 \mathrm{~cm}}=$ absorption coefficient of $\beta$-carotene in Petroleum Ether (2592).

\subsubsection{Sample Extraction for Phytochemicals}

About $5 \mathrm{~g}$ dried and crushed samples were weighed into a $250 \mathrm{~mL}$ conical flask and about $100 \mathrm{~mL}$ methanol added. The flask was closed securely using parafilm and covered with aluminum foil. The samples were put in a shaker and shaken for about 3 hours. They were then kept in the dark and left to extract for 72 hours.

After 72 hours, the samples were filtered through Whatman No. 4 filter paper, and then the filtrate concentrated in a vacuum evaporator to a volume of $20 \mathrm{~mL}$. The extract was transferred into vial bottles and securely stoppered.

This extract was used for analysis of flavonoids and anti-oxidative activity.

\subsubsection{Determination of Flavonoids}

Qualitative analysis: This was done according to the method of Harborne (1973); $5 \mathrm{~mL}$ of dilute ammonia solution was added to a portion of aqueous filtrate of extract followed by addition of concentrated $\mathrm{H}_{2} \mathrm{SO}_{4}$. A yellow coloration observed indicated the presence of flavonoids. The yellow coloration disappeared on standing.

Quantitative analysis: Aluminum chloride colorimetric method was used for determination of flavonoids (Jagadish et al., 2009). To $10 \mathrm{~mL}$ volumetric flask $4 \mathrm{~mL}$ of distilled water and $1 \mathrm{~mL}$ of plant extract $(10 \mathrm{mg} / \mathrm{mL})$ were added. After 3 minutes, $0.3 \mathrm{~mL}$ of $5 \%$ sodium nitrite solution was added. After 3 minutes, $0.3 \mathrm{~mL}$ of $10 \%$ aluminum chloride was added. After 5 minutes, $2 \mathrm{~mL}$ of $1 \mathrm{M}$ sodium hydroxide was added and the volume made up to $10 \mathrm{~mL}$ with water. Absorbance was measured in UV-Vis spectrophotometer (Shimadzu model UV - 1601 PC, Kyoto, Japan) at $415 \mathrm{~nm}$. The percentage of total flavonoids was calculated from calibration curve of standard prepared from quercetin.

\subsubsection{Determination of the Free Radical Scavenging Activity}

The radical scavenging activities of the plant extracts against 2,2-Diphenyl-1-picryl hydrazyl (DPPH) radical (Sigma-Aldrich) were determined by UV spectrophotometer at $517 \mathrm{~nm}$ (Molyneux, 2004). The following concentrations of the extracts were prepared, $0.01,0.1,1.0,2.0$ and $5 \mathrm{mg} / \mathrm{mL}$ in methanol (Analar grade). Vitamin $\mathrm{C}$ was used as the antioxidant standard at concentrations of same as the extract concentrations. A $1 \mathrm{~mL}$ of the extract was placed in a test tube, and $3 \mathrm{~mL}$ of methanol was added followed by $0.5 \mathrm{~mL}$ of $1 \mathrm{mM}$ DPPH in methanol. A blank solution was prepared containing the same amount of methanol and DPPH. Methanol was used to zero the spectrophotometer and the absorbances were read in UV-Vis spectrophotometer (Shimadzu 
model UV - $1601 \mathrm{PC}$, Kyoto, Japan) at $517 \mathrm{~nm}$ after 5 minutes. The radical scavenging activity was calculated using the following formula:

$$
\% \text { inhibition of } \mathrm{DPPH}=\{(\mathrm{AB}-\mathrm{AA}) / \mathrm{AB}\} \times 100
$$

Where $\mathrm{AB}$ is the absorption of blank sample and $\mathrm{AA}$ is the absorption of tested extract solution.

The results were expressed as percentage inhibition of DPPH and mean inhibitory concentrations $\left(\mathrm{IC}_{50}\right)$ determined from a plot of $\%$ inhibition of DPPH versus concentration of extract.

\subsection{Data Management and Analysis}

The data was analyzed statistically using analysis of variance at $5 \%$ level of significance using the statistical software Genstat Release 14.1, and the means were separated using Duncan's Multiple Range Test (DMRT) to determine whether there was significant difference in anti-nutrients and phytochemicals among the varieties at the two harvest stages.

\section{Results and Discussion}

\subsection{Nitrate Content in the Amaranth Samples}

Nitrate contents varied significantly among the varieties at both the vegetative and post flowering stages. There was significant decrease in the mean nitrate content from $182 \mathrm{mg} / 100 \mathrm{~g}$ at vegetative stage to $121 \mathrm{mg} / 100 \mathrm{~g}$ at post flowering stage (Table 2). High level of nitrates when ingested can be converted to nitrite which can lead to cancer and metheamoglobinemia or blue-baby disease (Gupta et al., 2000; Macrae et al., 1997; Oguchi et al., 1996; Takebe \& Yoneyame, 1997). Nitrates can, however, be removed from amaranth leaves by boiling them in water for five minutes and discarding the water (Ogbadoyi et al., 2006).

Table 2. Nitrates in $100 \mathrm{~g}$ of the Fresh Amaranth Leaves

\begin{tabular}{lll}
\hline \multirow{2}{*}{ Variety } & \multicolumn{2}{c}{ Nitrates (mg) } \\
\cline { 2 - 3 } & \multicolumn{1}{c}{$\mathrm{H} 1$} & \multicolumn{1}{c}{$\mathrm{H} 2$} \\
\hline 1 & $175.1 \pm 0.5^{\mathrm{cd}}$ & $101.3 \pm 1.3^{\mathrm{a}}$ \\
2 & $203.9 \pm 1.2^{\mathrm{f}}$ & $110.6 \pm 5.1^{\mathrm{b}}$ \\
3 & $193.7 \pm 2.9^{\mathrm{e}}$ & $124.9 \pm 0.2^{\mathrm{d}}$ \\
4 & $196.2 \pm 0.3^{\mathrm{e}}$ & $121.6 \pm 2.5^{\mathrm{cd}}$ \\
5 & $183.7 \pm 2.9^{\mathrm{d}}$ & $133.0 \pm 0.6^{\mathrm{e}}$ \\
6 & $205.2 \pm 0.7^{\mathrm{f}}$ & $139.1 \pm 1.3^{\mathrm{e}}$ \\
7 & $170.5 \pm 1.0^{\mathrm{bc}}$ & $120.9 \pm 0.7^{\mathrm{c}}$ \\
8 & $166.4 \pm 3.7^{\mathrm{ab}}$ & $110.1 \pm 1.7^{\mathrm{b}}$ \\
9 & $164.4 \pm 2.6^{\mathrm{a}}$ & $120.4 \pm 1.3^{\mathrm{c}}$ \\
10 & $170 \pm 0.5^{\mathrm{abc}}$ & $137.7 \pm 1.1^{\mathrm{e}}$ \\
LDS (5\%) & 5.52 & 3.66 \\
Mean & 182.1 & 121.9 \\
\hline
\end{tabular}

H1- vegetative stage, H2-post flowering stage, Means within the same column with same superscripts were not significantly $(\mathrm{p} \leq 0.05)$ different. Values are presented as Mean $\pm \mathrm{SD}, \mathrm{n}=3$.

\subsection{Total Carotenoid Content in the Amaranth Samples}

The total carotenoids content in the samples ranged from $39.1-47.8 \mathrm{mg} / 100 \mathrm{~g}$ at vegetative stage and 41.2-47.3 $\mathrm{mg} / 100 \mathrm{~g}$ after flowering, with significant differences $(\mathrm{p} \leq 0.05)$ among the varieties. There was a significant decrease in the total carotenoid content from a mean of $42.5 \mathrm{mg} / 100 \mathrm{~g}$ at vegetative stage to a mean of 43.7 $\mathrm{mg} / 100 \mathrm{~g}$ at post flowering stage (Table 3). The carotenoid contents reduced in varieties 1 and 2, while the other eight varieties had slight increase in carotenoid content at post flowering stage. This shows that variety 1 and 2 have faster chlorophyll degradation than the other varieties. Carotenoids are yellow, red and orange pigments present in many fruits and vegetables. In the diet they act as powerful antioxidants and are believed to protect the 
body against free radical attack and reduce the incidence of cataracts, heart disease and certain cancers (Singh \& Rao, 2012).

\subsection{Vitamin C Content in the Amaranth Samples}

Amounts of ascorbic acid increased greatly as the plants grew older, (Table 3) with variety 7 increasing by up to $163 \%$; from $66.4 \mathrm{mg} / 100 \mathrm{~g}$ at vegetative stage to $175.9 \mathrm{mg} / 100 \mathrm{~g}$ at post flowering stage. Variety 1 , which had the highest amount at vegetative stage, had the least increase of $30 \%$ up from $117.1 \mathrm{mg} / 100 \mathrm{~g}$ at vegetative stage. The overall amounts are similar to reported values of $135 \mathrm{mg} / 100 \mathrm{~g}$ (Abukutsa-Onyango, 2003). Consumption of $100 \mathrm{~g}$ raw amaranth leaves can provide up to $270 \%$ of vitamin C daily requirement. Vitamin C (ascorbic acid) is however highly sensitive to air, light, temperatures and is also soluble in water. Hence most of it, $57 \%-78 \%$ has been reported to be lost during cooking of vegetables. Shorter cooking time is therefore recommended to avoid greater losses of this vitamin. Human beings cannot synthesize vitamin $C$, which is a very important antioxidant. Vitamin $\mathrm{C}$ is an important co-factor in protein chemistry and has many other uses. It strengthens immune system, fights infections, makes collagen, keeping bones, skin and joints firm and strong, antioxidant, protecting against cancer and heart disease (Harris, 1996).

Table 3. Vitamin $\mathrm{C}$ and carotenoid composition in $100 \mathrm{~g}$ fresh weight of the amaranth varieties at vegetative and post flowering stage

\begin{tabular}{lllll}
\hline \multirow{2}{*}{ Variety } & \multicolumn{2}{c}{ Ascorbic acid (mg) } & \multicolumn{2}{c}{ Total carotenoids(mg) } \\
\cline { 2 - 5 } & \multicolumn{1}{c}{$\mathrm{H} 1$} & $\mathrm{H} 2$ & $\mathrm{H} 1$ & $\mathrm{H} 2$ \\
\hline 1 & $117.1 \pm 3.9^{\mathrm{e}}$ & $152.7 \pm 4.1^{\mathrm{a}}$ & $44.7 \pm 1.1^{\text {ef }}$ & $41.2 \pm 1.3^{\mathrm{a}}$ \\
2 & $74.8 \pm 4.9^{\mathrm{b}}$ & $155.0 \pm 3.6^{\mathrm{ab}}$ & $47.8 \pm 2.1^{\mathrm{g}}$ & $41.5 \pm 0.5^{\mathrm{a}}$ \\
3 & $68.6 \pm 0.7^{\mathrm{a}}$ & $151.6 \pm 3.4^{\mathrm{a}}$ & $39.5 \pm 0.8^{\mathrm{ab}}$ & $42.0 \pm 0.8^{\mathrm{a}}$ \\
4 & $76.6 \pm 0.6^{\mathrm{b}}$ & $150.1 \pm 1.7^{\mathrm{a}}$ & $39.1 \pm 1.1^{\mathrm{a}}$ & $44.2 \pm 1.5^{\mathrm{b}}$ \\
5 & $85.1 \pm 3.5^{\mathrm{cd}}$ & $149.8 \pm 4.8^{\mathrm{a}}$ & $45.4 \pm 0.4^{\mathrm{f}}$ & $46.5 \pm 0.1^{\mathrm{c}}$ \\
6 & $82.1 \pm 3.4^{\mathrm{c}}$ & $176.2 \pm 0.4^{\mathrm{c}}$ & $43.2 \pm 0.5^{\mathrm{de}}$ & $44.2 \pm 0.2^{\mathrm{b}}$ \\
7 & $66.4 \pm 2.3^{\mathrm{a}}$ & $175.9 \pm 1.7^{\mathrm{c}}$ & $41.6 \pm 0.7^{\mathrm{cd}}$ & $42.6 \pm 0.2^{\mathrm{a}}$ \\
8 & $88.8 \pm 3.7^{\mathrm{d}}$ & $159.6 \pm 1.1^{\mathrm{b}}$ & $41.3 \pm 0.1^{\mathrm{bcd}}$ & $41.9 \pm 0.8^{\mathrm{a}}$ \\
9 & $85.5 \pm 0.5^{\mathrm{cd}}$ & $150.9 \pm 0.6^{\mathrm{b}}$ & $41.3 \pm 1.2^{\mathrm{bcd}}$ & $45.9 \pm 0.5^{\mathrm{c}}$ \\
10 & $84.9 \pm 1.1^{\mathrm{cd}}$ & $158.1 \pm 0.5^{\mathrm{b}}$ & $40.4 \pm 0.5^{\mathrm{abc}}$ & $47.3 \pm 0.5^{\mathrm{c}}$ \\
LSD (5\%) & 4.87 & 4.76 & 1.78 & 1.43 \\
Mean & 83 & 158 & 42.5 & 43.7 \\
\hline
\end{tabular}

H1- vegetative stage, H2-post flowering stage; Means within the same column with same superscripts were not significantly $(\mathrm{p} \leq 0.05)$ different. Values are presented as Mean $\pm \mathrm{SD}, \mathrm{n}=3$.

\subsection{Flavonoid Content in the Amaranth Samples}

Qualitative results of flavonoids: The preliminary phytochemical screening of the methanolic extract showed the presence of flavonoids.

At vegetative stage, flavonoid content ranged between $2819.9-4284.0 \mathrm{mg} / 100 \mathrm{~g}$ quercetine equivalent (QE), and $1446.5-2330.1 \mathrm{mg} / 100 \mathrm{~g} \mathrm{QE}$ at post flowering stage. There was significant decrease in the flavonoid content, from $3254 \mathrm{mg} / 100 \mathrm{~g}$ at vegetative stage to $2033 \mathrm{mg} / 100 \mathrm{~g}$ at post flowering stage (Table 4). These values are relatively lower compared to those reported by Olajire and Azeez (2011) which were $6967 \mathrm{mg} / 100 \mathrm{~g}$ in Amaranthus caudatus and much higher than those reported by Akubugwo et al. (2008). Flavonoids have been shown to have antibacterial, anti-inflammatory, anti-allergic, anti-neoplastic, antiviral, antithrombotic and vasodillatory activities (Miller, 1996). The potent antioxidant activities of flavonoids have been suggested to be responsible for many of the above actions, as oxidative damage is implicated in most disease processes. 
Table 4. Flavonoid content as quercetin equivalent and total antioxidant capacity of the dried amaranth leaves

\begin{tabular}{lllll}
\hline \multirow{2}{*}{ Variety } & \multicolumn{2}{c}{ Flavonoid (mg/100g QE) } & \multicolumn{2}{c}{ Antiox activity: $\mathrm{IC}_{50}(\mathrm{mg} / \mathrm{ml})$} \\
\cline { 2 - 5 } & \multicolumn{1}{c}{$\mathrm{H} 1$} & \multicolumn{1}{c}{$\mathrm{H} 2$} & \multicolumn{1}{c}{$\mathrm{H} 1$} & \multicolumn{1}{c}{$\mathrm{H} 2$} \\
\hline 1 & $4284.0 \pm 19.2^{\mathrm{i}}$ & $2330.1 \pm 2.8^{\mathrm{i}}$ & $2.3 \pm 0.17^{\mathrm{b}}$ & $1.2 \pm 0.1^{\mathrm{ab}}$ \\
2 & $3368.1 \pm 4.9^{\mathrm{g}}$ & $1929.5 \pm 12.5^{\mathrm{c}}$ & $2.3 \pm 0.29^{\mathrm{b}}$ & $1.5 \pm 0.4^{\mathrm{b}}$ \\
4 & $3629.9 \pm 15.3^{\mathrm{h}}$ & $1697.5 \pm 13.2^{\mathrm{b}}$ & $2.5 \pm 0.36^{\mathrm{b}}$ & $1.0 \pm 0.05^{\mathrm{a}}$ \\
5 & $3026.5 \pm 5.6^{\mathrm{c}}$ & $1975.9 \pm 16.1^{\mathrm{d}}$ & $2.2 \pm 0.17^{\mathrm{ab}}$ & $1.3 \pm 0.2^{\mathrm{ab}}$ \\
6 & $3170.1 \pm 7.0^{\mathrm{e}}$ & $2279.5 \pm 20.7^{\mathrm{h}}$ & $2.4 \pm 0.11^{\mathrm{b}}$ & $1.2 \pm 0.0^{\mathrm{ab}}$ \\
7 & $3002.9 \pm 2.7^{\mathrm{b}}$ & $2065.7 \pm 10.4^{\mathrm{e}}$ & $2.3 \pm 0.15^{\mathrm{b}}$ & $1.3 \pm 0.05^{\mathrm{ab}}$ \\
8 & $2819.9 \pm 12.5^{\mathrm{a}}$ & $2198.7 \pm 17.3^{\mathrm{g}}$ & $2.3 \pm 0.2^{\mathrm{b}}$ & $1.2 \pm 0.0^{\mathrm{ab}}$ \\
9 & $3201.0 \pm 8.4^{\mathrm{f}}$ & $2289.7 \pm 10.4^{\mathrm{h}}$ & $1.9 \pm 0.2^{\mathrm{a}}$ & $1.4 \pm 0.2^{\mathrm{ab}}$ \\
10 & $3048.9 \pm 4.9^{\mathrm{d}}$ & $1446.5 \pm 10.3^{\mathrm{a}}$ & $2.2 \pm 0.15^{\mathrm{ab}}$ & $1.1 \pm 0.3^{\mathrm{ab}}$ \\
LSD (5\%) & $2994.8 \pm 7.6^{\mathrm{b}}$ & $2117.5 \pm 10.3^{\mathrm{f}}$ & $2.5 \pm 0.2^{\mathrm{b}}$ & $1.0 \pm 0.1^{\mathrm{a}}$ \\
Mean & 18.22 & 21.61 & 0.34 & 0.36 \\
\hline
\end{tabular}

H1- vegetative stage, $\mathbf{H 2}$ - post flowering stage, $\mathbf{I C}_{50^{-}}$concentration at $50 \% \mathrm{DPPH}$ inhibition, QE- quercetin equivalent. Means within the same column with same superscripts were not significantly $(\mathrm{p} \leq 0.05)$ different. Values are presented as Mean $\pm \mathrm{SD}, \mathrm{n}=3$.

\subsection{Antioxidant Activity/ Free Radical Scavenging Activity}

The lower the $\mathrm{IC}_{50}$ value the higher the FRSA/antioxidant power. At vegetative stage, there was no significant difference $(\mathrm{p} \leq 0.05)$ in the antioxidant activity of seven varieties (Table 4$)$. Variety 8 had significantly higher antioxidant activity (lowest $\mathrm{IC}_{50}$ value, $1.9 \mathrm{mg} / \mathrm{ml}$ ) than other varieties but was not significantly different $(\mathrm{p} \leq 0.05$ ) with variety 4 and 9 at $2.2 \mathrm{mg} / \mathrm{ml}$. At post flowering stage, there was a significant rise in the antioxidant activity of all the vegetables to a mean $\mathrm{IC}_{50}$ of $1.2 \mathrm{mg} / \mathrm{ml}$ (Table 4). There was no significant difference $(\mathrm{p} \leq 0.05)$ among nine varieties. However, variety 2 had significantly lower antioxidant activity than variety 3 and 10 . The leaf extract of amaranth exhibited a good potential to act as a free radical scavenger. However the $\mathrm{IC}_{50}$ for $\mathrm{DPPH}$ inhibition for amaranths $(1.0-2.5 \mathrm{mg} / \mathrm{ml})$ was comparably lower to that of Vitamin $\mathrm{C}(0.004 \mathrm{mg} / \mathrm{ml})$ which is a known free radical scavenger.

High \% inhibition of DPPH is an indication of high free radical scavenging activity (FRSA) of the extract. The methanol extracts of the amaranth varieties showed potential of free radical scavenging activity against DPPH, which was, however, considerably lower compared to vitamin $\mathrm{C}$ as a free radical scavenger.

At vegetative stage, maximum inhibition was achieved at a high concentration of $5 \mathrm{mg} / \mathrm{ml}(57.7-64.2 \%)$ for the amaranth leaves compared to $0.1 \mathrm{mg} / \mathrm{ml}(98 \%)$ for Vitamin C (Figure 1). At post flowering stage, maximum inhibition was achieved at extract concentration of $5 \mathrm{mg} / \mathrm{ml}(63.1-71.8 \%)$ in the different varieties, and at 0.1 $\mathrm{mg} / \mathrm{ml}(98 \%$ ) for vitamin C (Figure 2). Hence a higher concentration of amaranth leaves will be required to achieve maximal inhibition of DPPH compared to Vitamin C. 


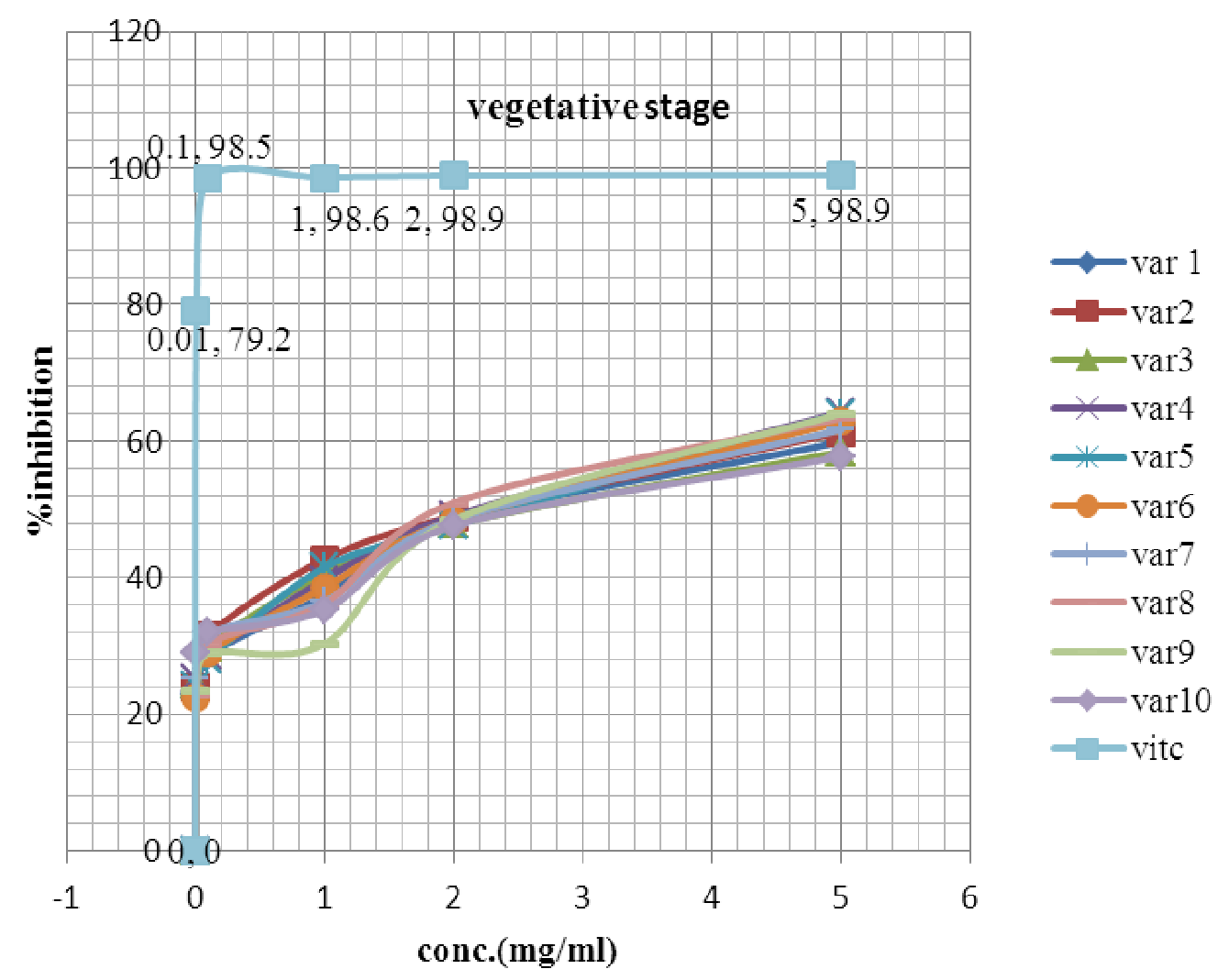

Figure 1. Inhibition (\%) of DPPH against concentration of extracts of amaranth leaves harvested at vegetative stage and Vitamin C

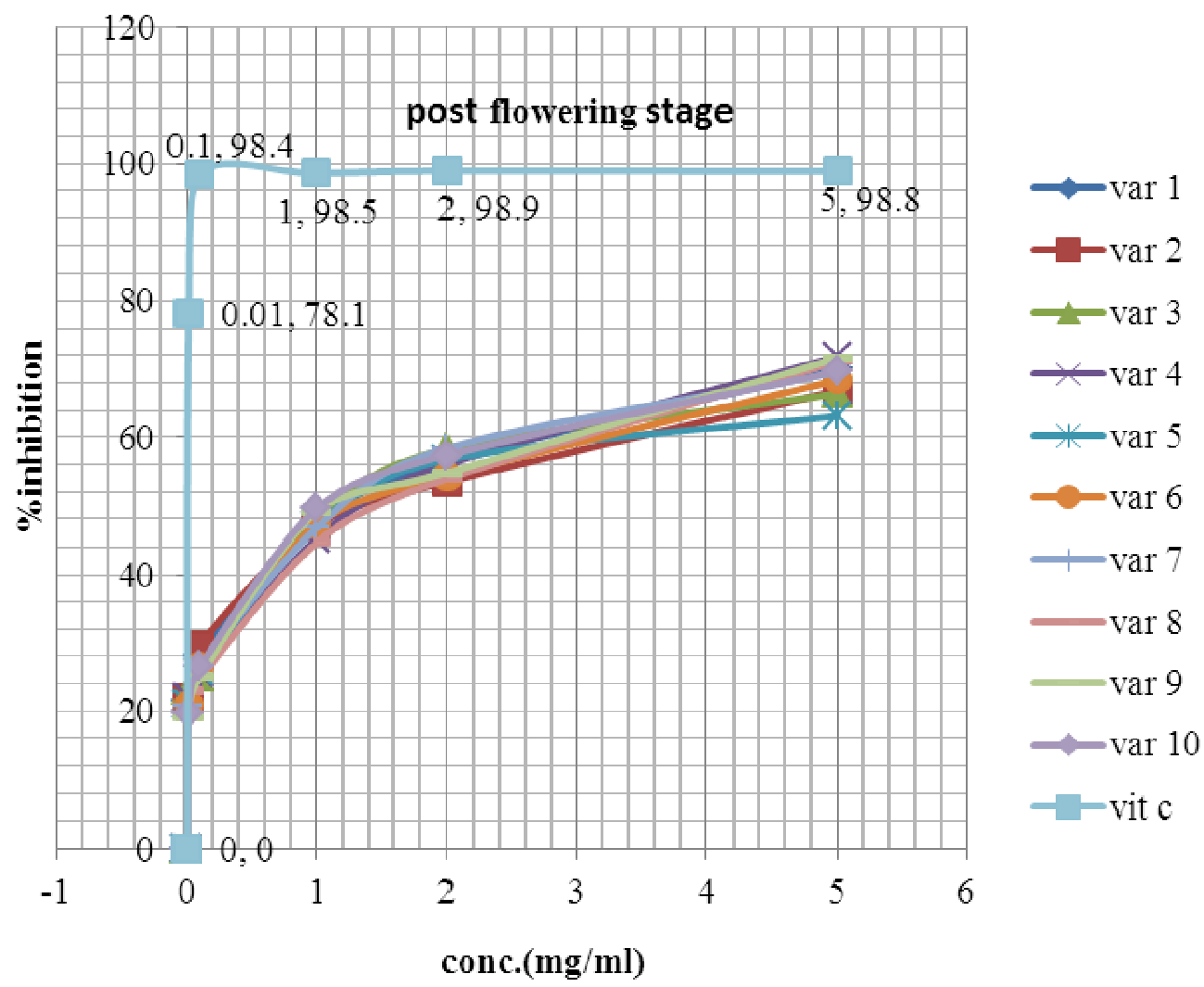

Figure 2. Inhibition (\%) of DPPH against concentration of extracts of amaranth leaves harvested at post flowering stage and Vitamin $\mathrm{C}$ 
The antioxidant activity is contributed to by the various phytochemicals with antioxidant activity. These include vitamin C, carotenoids and flavornoids. However, vitamin $\mathrm{C}$ is heat labile, it is also easily dissolved and most of it may have been lost during sample extraction for the antioxidant activity analysis.

\section{Conclusion}

There were significant differences $(\mathrm{p} \leq 0.05)$ in the phytochemical and anti-nutrient content among the varieties and at the different harvest stages. As the plants matured, the anti-nutrient content increased. The anti-nutrient activity also increased with maturity, from vegetative to post flowering stage. The amaranth leaves should be consumed before flowering as they have generally lower anti-nutrients. Selection of the varieties can be done according to their anti-nutrient and phytochemical content. Abuku amaranth 1 (A. blitum), Abuku amaranth 7 ( $A$. dubius) and Abuku amaranth 8 (A. hypocandracus) had the lowest anti-nutrients while Abuku amaranth 5 ( $A$. hydubius) and Abuku amaranth 8 (A. hypocandracus) had the highest phytochemicals. Among the ten varieties, Abuku amaranth 8 (A. hypocandracus) is therefore the best.

\section{Acknowledgements}

The authors are grateful to the Kenyan, National Commission of Science, Technology and Innovation (NACOSTI) for funding this research work (grant number NCST/5/003/3 ${ }^{\text {rd }} / \mathrm{STI} / \mathrm{CALL} / 89$ ) and to the Jomo Kenyatta University of Agriculture and Technology (JKUAT) Departments of Horticulture and Food Science and Technology for providing the land, facilities, laboratory and technical assistance.

\section{References}

Abara, A. E. (2003). Tannin Content of Dioscorea bulbufera. J. Chem. Soc. Nigeria, 28, 55-56.

Abukutsa-Onyango, M. O. (2003). Unexploited potential of indigenous African vegetables in Western Kenya. Maseno J. Edu. arts sci., 4, 103-122.

Agbaire, P. O., \& Emoyan, O.O. (2012). Nutritional and antinutritional levels of some local vegetables from Delta State, Nigeria. Afr. J. Food Sci., 6, 8-11. http://dx.doi.org/10.5897/AJFS111.175

Akubugwo, I. E, Obasi, N. A, Chinyere, G. C., \& Ugbogu, A. E. (2008). Mineral and phytochemical contents in leaves of Amaranthus hybridus $L$ and Solanum nigrum L. subjected to different processing methods. Afr. $J$. Biochem. Res., 2, 40-44. .

AOAC. (1996). Official Methods of Analysis 14th ed. Association of Official Analytical Chemists Washington, D.C.

Cataldo, D. A., Haroon, M., Schrader, L. E., \& Youngs, V. L. (1975). Rapid calorimetric determination of nitrate in plant tissue by nitration of salicylic acid. Soil Sci. Plant Anal., 6, 71-80. http://dx.doi.org/10.1080/00103627509366547

Grubben, G. J. H. (2004). Amaranthus cruentus L. In G. J. H. Grubben, \& O. A. Denton (Eds.), PROTA 2: Vegetables/ Legumes. PROTA, Wageningen, Netherlands.

Gupta, S. K., Gupta, R. C., Seth, A. K., Gupta, A. B., Bassin, J. K., \& Gupta, A. (2000). Methemoglobinemia-A problem of all age groups in areas with high nitrate in drinking water. Nat. med. J. India, 13, 58-61.

Harbone, J. B. (1973). Phytochemical Methods. London: Chapman and Hall Ltd.

Harris, J. R. (1996) Subcellular Biochemistry, Ascorbic Acid. Biochemistry and Biomedical cell biology, 25. New York: Plenum.

He, H. P., Cai, Y., Sun, M., \& Corke, H. (2002). Extraction and purification of squalene from amaranthus grain. $J$. Agric. Food Chem., 50, 368-372. http://dx.doi.org/10.1021/jf010918p

Jacob, A. (2005). The Africa exeutive magazine. A Plant Full of Medicinal Values. Retrieved from http://www.africanexecutive.com/modulecs/magazine/articles.php?article=331

Jagadish, L. K., Krishnan, V. V., Shenbhagaraman, R., \& Kaviyarasan, V. (2009). Comparative study on the antioxidant, anticancer and antimicrobial property of Agaricus bisporus imbach before and after boiling. Afr. J. Biotechnol., 8, 654-661.

Kauffman, C. S., \& Weber, L. E. (1990) Grain Amaranth. In J. Janick \& J. E. Simon (Eds), Advances in New Crops (pp. 127-139). Portland, Oregon: Timber Press.

Kirk, H., \& Sawyer, R. (1998). Frait Pearson Chemical Analysis of Food (8th ed., pp. 211-212). Edinburgh: Longman Scientific and Technical. 
Macrae, R., Robinson, R. K., \& Sadler, M. J. (1997). Encyclopaedia of Food Science. Food Technology and Nutrition, 7, 4715-4757. New York: Academic Press.

Miller, A. L. (1996). Antioxidant Flavonoids: Structure, Function and Clinical Usage. Alt. Med. Rev., 1(2), 103-111.

Molyneux, P. (2004). The use of the stable free radical diphenylpicrilhydrazyl (DPPH) for estimating antioxidant activity. Song klanakarin J. Sci. Technol., 26, 211-219.

Ogbadoyi, E. O., Makun, A. H., Bamigbade, O. R., Oyewale, O. A., \& Oladiran, J. A. (2006). The effect of processing and preservation methods on the oxalate levels of some Nigeria leafy vegetables. Biokemistri, 18, $121-125$.

Oguchi, Y., Weerakkody, W. A. P., Tanaka, A., Nakazawa, S., \& Ando, T. (1996). Varietal differences of quality-related compounds in leaves and petioles of spinach grown at two locations. Bull. the Horishima Prefectural Agric. Res. Center, 64, 1-9.

Olajire, A. A., \& Azeez, L. (2011). Total antioxidant activity, phenolic, flavonoid and ascorbic acid contents of Nigerian vegetables. Afr. J. Food Sci. and Technol., 2, 22-29.

Raheena, B. (2007). Food, Nutrition and Dietetics (2 ed., pp. 106-109). Delhi: Sterling Publisher Private Limited.

Rodriguez-Amaya, D. B., \& Kimura, M. (2004) HarvestPlus Handbook for Carotenoid Analysis. HarvestPlus Technical Monograph 2.

Santos-Buelga, C., \& Scalbert, A. (2000). Proantocyanidins and tannin-like compounds: nature, occurrence dietary intake and effects on nutrition and health. J. Sci Food \& Agric., 80, 1094-1117. http://dx.doi.org/10.1002/(SICI)1097-0010(20000515)80:7<1094::AID-JSFA569>3.0.CO;2-1

Singh, P. K. \& Rao, K. M. (2012). Phytochemicals in vegetables and their health benefits. Asian J. Agric. Rural Dev., 2, 177-183.

Takebe, M., \& Yoneyama, T. (1997). Effect of ammonium-nitrogen supply on oxalic acid content in spinach grown in hydroponic foods. Plant nutrition-for Substainable food production and environment (pp. 957-958), Kluwer Academic Publisher. http://dx.doi.org/10.1007/978-94-009-0047-9_310

Vikram, V. B., Ramesh, M. N., \& Prapulla, S. G. (2005). Thermal degradation kinetics of nutrients in orange juice heated by electromagnetic and conventional methods. J. Food Eng, 69, 31-40. http://dx.doi.org/10.1016/j.jfoodeng.2004.07.013

\section{Copyrights}

Copyright for this article is retained by the author(s), with first publication rights granted to the journal.

This is an open-access article distributed under the terms and conditions of the Creative Commons Attribution license (http://creativecommons.org/licenses/by/3.0/). 